International Journal of Current Aspects in Finance, Banking and Accounting, Volume 3, Issue 2, 2021 PP 65-78, ISSN 2707-8035

\title{
Macroeconomic Effects of Initial Public Offer and Performance Equity Prices of Firms Listed in Nairobi Securities Exchange, Kenya
}

\author{
Wachira Moses Muchemi, Peter Ng'ang'a
}

Department of Accounting and Finance, School of Business, Kenyatta University, Kenya

\begin{abstract}
Market reacts differently to various factors ranging from economic political, and sociocultural. The stock prices of quoted companies in Kenya are affected either positivity or negatively by a number of factors occurring within or without the economic system. Initial public offering is often issued by smaller, younger companies seeking the capital to expand, but can also be done by large privately owned companies looking to become publicly traded. The initial public offering is a vital step for young entrepreneurial firms, providing them access to the public equity market for the first time. Previous literature had focused primarily on initial public offering under-pricing phenomenon to measure the performance of companies. However, researchers argued that initial public offering pricing, which was a key factor in under-pricing had remained relatively unexplored in literature. The study employed descriptive research design. The study targeted a total population of 7 quoted companies in Nairobi security market, which had issued IPO from 2006-2020. The study depended on secondary data collected from the Nairobi Securities Exchange. Data was analysed by the use of SPSS. From the panel regression analysis, the interclass correlation (rho) was 0.310 implying that $31 \%$ of the variations in equity share prices are due to differences among the quoted firms. The within and between $R$-square was 0.0154 and 0.9967 respectively. The overall $R^{2}$ was 0.9885 , indicating that the variables considered in the model account for about $98.85 \%$ percent change in the dependent variables, while the remaining percent change may be as a result of other variables not addressed by this model. Dividend per share improved significantly after the IPO. Dividend per share was also established to improved significantly after the IPO. The study concludes that dividend per share, market capitalization and market liquidity improved in the post going public period. This is due to the proceeds received by companies from the sale of their shares to the public. In addition, the study concludes that firms benefit by going public despite potentially higher agency problems, at least for the first few years after the IPO. Becoming publicly traded provides financial capital to firms that helps them commercialize their products.
\end{abstract}

Key Words: Initial Public Offers, Share Price, Equity Prices, Dividend Policy

DOI: $10.35942 /$ ijcfa.v3i2.197

\section{Cite this Article:}

Wachira, M., \& Ng'ang'a, P. (2021). Macroeconomic Effects of Initial Public Offer and Performance Equity Prices of Firms Listed in Nairobi Securities Exchange, Kenya. International Journal of Current Aspects in Finance, Banking and Accounting, 3(2), 65-78. https://doi.org/10.35942/ijcfa.v3i2.197

\subsection{Introduction}

The initial public offer (IPO) is a basic strategy for youthful entrepreneurial companies, enabling them to access the general population equity market. It is the primary sale of stock by a privately owned business to the general population and the consequential listing on a stock trade. Opening up to the world permits firms to raise and get funds important to quicken development so as to accomplish market leadership (Ernst and Young, 2010). What's more, the 
International Journal of Current Aspects in Finance, Banking and Accounting, Volume 3, Issue 2, 2021 PP 65-78, ISSN 2707-8035

liquidity made by opening up to the world gives initial inventors, proprietors, and shareholders with an opportunity to gather on their investment. Besides, an IPO can encourage future acquisitions, higher valuations, obligation as well as open profile improvement (Blum, 2011). Recent research looked at the valuing mechanism utilized at the IPO. As indicated by (Kipngetich et al 2011), Initial Public Offerings (IPO) include issues with respect to value disclosure because of uncertainties in regards to total demand as well as issuer quality. Bensveniste and Spindt (1989) contend that issuers can feign themselves to financial specialists as being of high reputation than they seem to be. Derrien (2005) agrees that valuing of IPOs can be a tough assignment because of obscurity of finding a proper similar firm.

Research accessible mainly in developed nations has reported the degree of under-estimating of IPO's without distinguishing the fundamental variables required in setting the IPO offer cost. Numerous scholars (Cornelli, 2004; Ljungqvist, 2006 and Purnanandan and Swaminathan, 2003). Under - estimating alludes to the rate contrast between the offer cost and the first day. This phenomenon contradicts one of the real purposes for organizations opening up to the world, which is to raise assets to bolster extension of the firm. It additionally repudiates effective business sector speculation, which proposes that security costs completely reflect all publicly and secretly accessible data. When contrasted with created markets the number of organizations opening up to the world in Kenya was low. Corwin, (2003) distinguishes uncertainty and asymmetric data as a solid impact on an association's equity pricing and in actuality lead to under-estimated instrument. The business sector is data delicate. Easley, Hridkjaer and O'Hara (2001) concur that business sector is data delicate in any event to the degree that insider data influence value returns and exhorted that it ought not be disregarded for proficient resource evaluating, Kang (2008). The components influencing the cost of equity share can be looked into from the macro as well as micro economic perspectives.

Since dividends are paid quarterly, organizations will issue dividends based on their net earned for the quarter. Even though dividends are not guaranteed, investors should expect to get similar amount as the previous quarter. However, if an investor determines that the dividend pay-out might be higher than the previous quarter; this affects the price of the stock. Each dividend, a corporation pays to stockholders is declared by the company's board of directors (Mark, 2012). Earnings per share is used to calculate the widely used ratio PE Ratio; PE Ratio = Share Price/EPS; by combining it with a forecast of companies' earnings analysts can describe whether the shares are over or under valued (IAS 33 Earnings Per Share). The PE ratio reflects investors' hopes about the world wide performance of the company and the industry sector. High PE Ratio may reflect investor confidence in the existing administration; it can also reflect lack of investor confidence in the existing management team but an anticipation of a takeover. Low PE Ratio could show a lack of confidence in the recent administration or a feeling that a new administration might find problems that are not easily sorted.

The exchange rate is the estimation of the American dollar versus different monetary standards. The estimation of the dollar is both brought on and reflected by loan fees, and premium rates have much to do with stock costs. The effect of Exchange rate on Equity prices. Accordingly, trade rates influence stock costs and can be utilized to make forecasts about the business sector. A feeble dollar implies American products are less expensive abroad. As indicated by Corrado and Jordan (2002), a portion of the components impacting stock value conduct incorporate organization benefits; political variables; and monetary execution. Others are financing costs; inflationary rate; Real Gross Domestic Product; and shareholder-level charges. Interest in securities exchange is long haul in nature; any advancement that could influence the strength of the commonwealth or economy ordinarily has genuine effect on the stock costs. In Kenya, 2008 it looked as if Kenya's securities exchange may proceed with its bull run of late years. In any case, recorded values on the Nairobi Stock Exchange (NSE) unavoidably used a similar 
International Journal of Current Aspects in Finance, Banking and Accounting, Volume 3, Issue 2, 2021 PP 65-78, ISSN 2707-8035

descending slide as whatever is left of the universe even though not necessarily for a similar purpose. The outcome was approximately 35\% reduction in the NSE's benchmark list, the Nairobi Stock Exchange 20 Share Index throughout the year, closing the year 2008 at 3,521.18, a three-year low, contrasted with 2007's end of 5,444.83. A decent arrangement offering was by remote speculators that had previously heaped into the bullish Kenyan values market, neighbourhood. As the violence waned and financial specialists came back to the NSE, one of the nation's biggest retail-based venture houses crumpled and numerous retail financial specialist were lost (NSE, 2021). Others continued to work, with an expectation of a mid-year help from the first sale of stock (IPO) in March and April of mobile-phone network provider Safaricom, the trusts fell the oversubscribed offer value increased rapidly yet placed underneath the cost offer.

\subsection{Statement of the Problem}

The short and long-term performance of newly issued equity has been of significant interest to investors. However, benefits to individual investors are not always clear when it comes to returns offered by the price used in the investment of shares in the stock market. Researchers abroad have suggested that investing in new ordinary equity results to cascading returns (high initial returns in the short term and poor performance over the long term). Braun and Larrain (2007) affirm that IPOs do not go unnoticed in emerging markets. They add that IPOs are focal points, particularly if they are listed alone and they can stir the whole market. A single large IPO can have a significant effect in a less developed market. The sheer size of these transactions attracts the attention of all big investors such as pension funds and international funds. The nature of emerging markets is such that prices can never be assumed to reflect all information available. Where investors cannot correctly interpret information that is released and as such there is great potential for prices to move in a manner not justified by the information available, this raises important questions regarding the efficiency of the stock market and the effect of such conditions on stock returns. The level of initial returns reaching unprecedented peaks and long-term under performance of the share price, the search for the reasons of these anomalies is still unresolved (Durukan, 2002).

Labidi and Triki (2011) sought to find out if there were anomalous patterns, namely underpricing and long-run under-performance, in the stock price behaviour of companies that go public in the Middle East and North Africa (MENA) region and the impact of investors' optimism and divergence of opinions on IPO under-pricing and long-term under-performance. The study was however done from an international setting hence the findings cannot be equally compared locally. Most Kenyan studies have focused on under-pricing and performance of IPOs without taking into consideration the effect on equity share prices such as Ngahu (2006) on book value per share issue price and first trading day prices of IPOs at NSE, Cheluget(2008) on investors' demand for IPOs and first day performance: evidence from NSE, Ndatimama (2008) on performance of IPOs, Leshore (2008) on medium-term performance of IPOs, Simiyu (2008) on pricing and performance of initial public offering: a comparison between 9 state owned enterprises and privately owned enterprises at NSE, Thuo (2009) on the short-run performance of IPOs, Karitie (2010) on long-run performance of IPOs, Wachira (2010) on the determinants of the success of IPOs among listed companies and Kipngeetich et al (2011) on determinants of IPO pricing in Kenya. This show that though studies have been conducted in the field, the is still inconclusiveness on the exact impact of IPO on equity share prices. Due to this lack of sufficient literature the effect of IPOs on the stock prices at the NSE remains largely unexplained necessitating this study. This research was based on identifying these various anomalies. 
International Journal of Current Aspects in Finance, Banking and Accounting, Volume 3, Issue 2, 2021 PP 65-78, ISSN 2707-8035

\subsection{Objective of the study}

The general objective of the study is to determine the macroeconomic effects of initial public offer and performance equity prices of firms listed in Nairobi Securities Exchange (NSE), Kenya.

Specific objectives were:

i. To determine the effect of dividend per share on equity prices of quoted companies at NSE post IPO.

ii. To determine the effect of market capitalization on equity prices of quoted companies at NSE post IPO.

iii. To determine the effect of market liquidity on equity prices of quoted companies at NSE post IPO.

iv. To determine the effect of foreign exchange rate on equity prices of quoted companies at NSE post IPO.

\subsection{Literature Review}

\subsection{Theoretical Review}

Theoretical review of the study was based on market efficient hypothesis, which indicates that IPOs are among the most important practical factors that can be used to predict the market performance (Market index).

\subsubsection{Random Walk Theory}

The Efficient Markets Hypothesis (EMH), popularly known as the Random Walk Theory by Fama (1970), is the proposition that current stock prices fully reflect available information about the value of the firm, and there is no way to earn excess profits, more than the market over all, by using this information (Fama,1970). The primary purpose of EMH was to demonstrate that stock prices accurately and quickly reflected all available information in such a way that no one can earn abnormal returns. The time for adjusting any information is considered a critical factor. If the markets adjust more rapidly and accurately, it is considered more efficient. Dyckman and Morse (2006) states that a security market is generally defined as efficient on condition that the prices of securities traded in the market act as though they fully reflect all available information, these prices react instantaneously, or nearly so and in an unbiased fashion to new information. Market efficiency does not imply that no investor can be at the market at any time period or that stock prices cannot deviate from true value and also that no group of investors will be able to beat the market in the long run. However, market efficiency should mean that no investor should beat the market consistently but if this occurs, then it should be as a result of luck and not investment strategies.

The theory asserts that the stock market context does not mean, neither should it be taken to imply, that the price movements are whimsical and chaotic Mlambo (2003). All it means is that period-to-period price changes should be statistically independent and unforecastable if they are properly anticipated. Price movements are a perfectly rational response to information but since there is no reason to expect new information to be non-random, price changes based on this information is supposed to be random and uncorrelated to any observable trend (Fama, 1970). The theory argues that the share price movements are independent of one another and unrelated. This happens in an efficient market where the current prices of securities represent unbiased estimates of their intrinsic values. The random walk theory holds that the prices move in a random manner hence, it is not possible to predict future prices. The price movement, whether up or down, occurs as a result of new information and since investors cannot predict the kind of new information (whether good or bad), it is not possible to predict future price 
International Journal of Current Aspects in Finance, Banking and Accounting, Volume 3, Issue 2, 2021 PP 65-78, ISSN 2707-8035

movement.

The random walk theory clearly conflicts with technical analysis. The theory says that previous price changes or changes in returns are useless in predicting future prices, which implies that the work of a technical analyst is unnecessary. According to Fisher \& Jordan (1995); Mlambo (2003) the random walk theory is a special case of a more general efficient market hypothesis and the two positions complement each other. Lumby (1994) asserts that the theory of market efficiency and stock prices behaviour is inseparable. In Lumby (1994), the efficient market has been defined as a market where prices of a company's shares (or other financial securities) rapidly and correctly reflect all relevant information as it becomes available. No undervalued securities exist in such a market hence, the share prices can be relied upon to correctly reflect the true economic worth of the shares. Jensen (1978) points out that a market is efficient with respect to information if it is impossible to make abnormal economic profits by trading on the basis of that information. In an efficient market, competition among the many intelligent participants leads to a situation where, at any point in time, actual prices of individual securities already reflect the effects of information based both on events that have already occurred and on events which as of now the market expects to take place in the future. In other words, in an efficient market at any point in time the actual price of a security will be a good estimate of its intrinsic value.

\subsubsection{Dividend Relevance Theory}

Gordon (1963) gave a view about the dividend policy by presenting the concept of dividend relevance theory. Dividend relevance theory suggests that investors are generally risk averse and would rather have dividends today ("bird-in-the-hand") than possible share appreciation and dividends tomorrow. Dividend relevance theory proposes that dividend policy affect the share price. Therefore, according to this theory, optimal dividend policy should be determined which will ensure maximization of the wealth of the shareholders. If the choice of the dividend policy affects the value of a firm, it is considered as relevant. In that case a change in the dividend payout ratio will be followed by a change in the market value of the firm. If the dividend is relevant, there must be an optimum payout ratio. Optimum payout ratio is that ratio which gives highest market value per share. James (2001) argues that the choice of dividend payout ratio almost always affects the value of the firm. He studied the significance of the relationship between internal rate of return $(\mathrm{R})$ and cost of capital $(\mathrm{K})$ in determining optimum dividend policy, which maximizes the wealth of shareholders. Walter's model is based on the following assumptions: The firm finances its entire investments by means of retained earnings only, internal rate of return $(\mathrm{R})$ and cost of capital $(\mathrm{K})$ of the firm remains constant, the firms' earnings are either distributed as dividends or reinvested internally, the earnings and dividends of the firm will never change and the firm has a very long or infinite life. They said that dividend policy does affect the value of firm and market price of shares. Investors always prefer secure and current income in the form of dividends over capital gains. Lack and Scholes (1974) found no relationship between dividend policy and stock prices. Their results further explain that dividend policy does not affect the stock prices and it depends on investors' decision to keep either high or low yielding securities; return earned by them in both cases remains the same. Empirical studies do not support dividend relevance theory. However, actions of market participants tend to suggest that there is some connection between dividend policy and share price.

\subsubsection{Dividend Irrelevance Theory}

Much like their work on the capital-structure irrelevance proposition, Modigliani and Miller Theorem- MMT (1961) also theorized that, with no taxes or bankruptcy costs, dividend policy is also irrelevant. This is known as the "dividend-irrelevance theory", indicating that there is 
International Journal of Current Aspects in Finance, Banking and Accounting, Volume 3, Issue 2, 2021 PP 65-78, ISSN 2707-8035

no effect from dividends on a company's capital structure or stock price. MM's dividend-irrelevance theory (1961) says that investors can affect their return on a stock regardless of the stock's dividend. For example, suppose, from an investor's perspective, that a company's dividend is too big. That investor could then buy more stock with the dividend that is over the investor's expectations. Likewise, if, from an investor's perspective, a company's dividend is too small, an investor could sell some of the company's stock to replicate the cash flow he or she expected. As such, the dividend is irrelevant to investors, meaning investors care little about a company's dividend policy since they can simulate their own. The M\&M dividend irrelevance proposition has provided the foundation for much subsequent research on dividend policy. However, as stated by Ball et al. (1979, p.14), empirical tests of M\&M's "dividend irrelevance theorem have proven difficult to design and to conduct". Recall that M\&M built their conclusions on a certain set of assumptions of perfect capital markets. Relaxing one or more of these assumptions has formed the basis for most of theoretical and empirical studies.

In line with the dividend irrelevance hypothesis, Black and Scholes Black-Scholes formulae by Fischer Black, Myron Scholes and Robert Merton(1973) used a long-term definition of dividend yield (previous year's dividends divided by the year-end share price). Their results showed that the dividend yield coefficient (is not significantly different from zero either for the entire period (1936-1966) or for any of shorter sub-periods. That is to say, the expected return either on high or low yield stocks is the same. Therefore, Black-Scholes concluded that, "we are unable to show that differences in yield lead to differences in stock prices." Stated another way, in their study neither high-yield nor low-yield payout policy of firms seemed to influence stock prices. Black and Scholes's conclusion lent important empirical support to M\&M's dividend irrelevance argument.

Other studies by leading financial economic researchers such as Miller and Scholes (1978,1982), Hess (1981) Miller (1986), and more recently, Bernstein (1996) provided evidence in support of the dividend irrelevance hypothesis (hereafter DIH). While some empirical research supported the DIH (Dividend Irrelevance Hypothesis), other research was not so supportive or provided evidence directly challenging the irrelevance hypothesis. Building on Black and Scholes's work, Ball et al. (1979) examined the effect of dividends on firm value using Australian data over the period 1960 to 1969. Ball et al., However, failed to find conclusive evidence to support M\&M's irrelevance proposition. Baker, Farrelly and Edelman (1985) surveyed the chief financial officers (CFOs) of 562 firms listed on the New York Stock Exchange (NYSE) from three industry groups (150 utilities, 309 manufacturing, and 103 wholesale/retail). Based on 318 responses, they found that respondents strongly agreed that dividend policy affects common stock prices.

In another survey study, Partington (1985) found that Australian senior managers viewed dividend payments as a way to satisfy shareholders and support the share price. In a more recent study, Baker and Powell (1999) surveyed 603 CFOs of US firms listed on the NYSE, and observed that 90 percent of respondents believed that dividend policy affects a firm's value as well as its cost of capital. Further studies by the same authors tend to confirm that dividend policy actually matters in the determination of firm value. Other studies including Siddiqi (1995) and Casey and Dickens (2000) have provided evidence inconsistent with DIH. Despite all the empirical work testing the $\mathrm{DIH}$, the impact of dividend policy on the value of a firm remains unresolved. As showed earlier, the proposition of dividend irrelevancy was based on several binding assumptions about the nature of perfect capital markets. This is an 'a priori' model of how markets should work if they were perfect. Naturally, once we depart M\&M's (1961) world of prefect capital market and relax one or more of the assumptions of perfect capital markets, the issue of dividend policy becomes more complicated. 
International Journal of Current Aspects in Finance, Banking and Accounting, Volume 3, Issue 2, 2021 PP 65-78, ISSN 2707-8035

\subsection{Empirical Literature Review}

Gordon (1959) pointed out that investors pay three things when paying for the shares listed namely: both the dividends and the earnings, the dividends, and the earnings. Since dividends are paid quarterly, organizations will issue dividends based on their net earned for the quarter. Even though dividends are not guaranteed, investors should expect to get similar amount as the previous quarter. However, if an investor determines that the dividend pay-out might be higher than the previous quarter; this affects the price of the stock. Each dividend, a corporation pays to stockholders is declared by the company's board of directors (Mark, 2012). Dividends are mostly paid out by companies that are in a better cash position and whose earnings can be said to best able and sound (Kania\& Bacon, 2005). According to Denis and Osobov (2008), large, mature and more profitable firms are thought to be highly probable to pay dividends as they can even source for such funds to pay out dividends from cheap external debt sources at their disposal. Erick (2010) also establishes that the firm's liquidity position, its earnings and leverage, the profitable opportunities available and its debt to equity ratio are important determinants of dividend payments by firms from the financial sector listed at the Nairobi Securities Exchange (NSE).

Muriuki (2010) study revealed that announcement of a dividend by a firm had a short term influence on share prices. In a semi strong form market efficiency, stock prices reflected all publicly available information (Fama et al., 1969). This would lead to an adjustment to stock price when a dividend announcement was made. Vazakidis and Athianos (2010) observed a positive market reaction during the period before the dividend announcements, while negative abnormal returns were observed in the first days of post announcement period. Mukora (2014) found a positive effect of dividend announcement on stock returns for firms listed at the Nairobi Securities Exchange. Andres et al. (2009) showed that stock market returns were affected by unexpected dividend changes. According to Gurgul and Majdosz (2005), dividend announcements do affect stock returns in the Polish stock market. Historically, due to a lack of complete and accurate information available to shareholders, the cash flow provided by a security to an investor often formed the basis for its market valuation (Baskin and Miranti, 1997). In this way dividends came to provide a useful tool for managers in which to convey their private information to the market because investors used visible (or actual) cash flows to equity as a way of valuing a firm. Many scholars also suggest that dividends might have implicit information about a firm's prospects.

According to Hersh Shefrin and Meir Statman (June 2000), Stocks that pay consistent dividends are popular among investors. Though dividends are not guaranteed on common stock, many companies pride themselves on generously rewarding shareholders with consistent - and sometimes increasing - dividends each year. Companies that do this are perceived as financially stable, and financially stable companies make for good investments - especially among buy-and-hold investors who are most likely to benefit from dividend payments. Nyanaro, (2016) conducted a study on economic development in the East African community. The quantitative research methods were employed to define the nature of relationship between the variables. The results indicated a significant long run association amid market capitalization and GDP growth. The relationship was negative in the short-term nonetheless constructive in the long-term. The study however did not investigate the influence of capital market capitalization after IPO.

Mogaka, (2015) conducted study on the effect of capital market capitalization on mortgage growth in Kenya. The study data was collected from 1984 to 2013 and analysed using stepwise regression. The study established a positive relationship between the study variables but concentrated entirely in the real estate market which is not similar to the quoted firms in Kenya. 
International Journal of Current Aspects in Finance, Banking and Accounting, Volume 3, Issue 2, 2021 PP 65-78, ISSN 2707-8035

Skamo, (2012) investigated the relationship between profitability of banks at the NSE and market capitalization. The study used data for a period of 2007 and 2011 collected using secondary data collection sheet. Regression and correlation analysis were employed in the data analysis. The study found a weak positive effect brought about by market capitalization. The study however was not able to distinguish the reason(s) behind this weak effect.

Munene, (2017) conducted a study on the effects of market capitalization in Kenya. Experimental research designs were employed by the study and data analysed using time series for a period of 1990 to 2015 aided using E-views. Though a positive interact was found between capitalization of the capital market on the economy, the study failed to account for the impacts on equity share prices. Adu, Marbuah and Mensah (2013) studied the long run growth effects of financial deepening taking the market liquidity in Ghana. The constructs of financial deepening included money supply ratio, deposit liabilities, private sector ratio and total domestic credit. The study found out that financial deepening has a positive effect on the economic growth apart from market liquidity. This current aimed at establishing whether the same positive effect exists in Kenya.

Adebayo, Olanrewaju, and Oluwayinka (2011) conducted a study on liquidity and profitability taking the case of Nigeria. The study collected data using questionnaires and published financial statements. The results from the hypothesis testing showed that there was a significant positive relationship between profitability of the commercial banks and liquidity. The current study aimed to ascertain whether the same positive relationship applies to the quoted firms. Ogbuagu, and Ewubare, (2017) conducted a study on capital market liquidity, economic growth and volatility. The study used a causality model using time series using data from the Central Bank of Nigeria. The findings of the study were that there was a positive relationship between market liquidity and economic growth. The study however concentrated entirely in Nigeria and did not establish the relationship in the short run in equity share prices.

Exchange rate fluctuations can have a substantial impact on your investment portfolio, even if you only hold domestic investments. For example, the strong dollar generally dampens global demand for commodities as they are priced in dollars. This lower demand can affect earnings and valuations for domestic commodity producers, although part of the negative impact would be mitigated by the weaker local currency. A strong currency can also have an effect on sales and profits earned overseas; in 2015, numerous U.S. multinationals attributed a hit to the topline and bottom-line from the stronger dollar. Of course, the effect of exchange rates on portfolio returns is well known. Investing in securities that are denominated in an appreciating currency can boost total returns, while investing in securities denominated in a depreciating currency can trim total returns. For instance, a number of European stock indices reached record highs in the first four months of 2015, but American investors who had invested in them would have seen their returns reduced substantially by the plunging euro.

As indicated by Corradoand Jordan (2002), a portion of the components impacting stock value conduct incorporate organization benefits; political variables; and monetary execution. Others are financing costs; inflationary rate; Real Gross Domestic Product; and shareholder-level charges. Interest in securities exchange is long haul in nature; any advancement that could influence the strength of the commonwealth or economy ordinarily has genuine effect on the stock costs. As of late, the NSE has reliably lost focuses and the costs of stocks have encountered sharp decline. The downward pattern in the business sector execution was ascribed to differing reasons in linewith those expressed by Corrado, et al (2002). However, Onagoruwa(2006) was of the view that stocks with history of good execution and central credits regard purchase now and again like this when their costs are down and more moderate since they are destined to ricochet back since they have the ability to assimilate the sorrow in 
International Journal of Current Aspects in Finance, Banking and Accounting, Volume 3, Issue 2, 2021 PP 65-78, ISSN 2707-8035

the business sector (Emmanuel and Samuel, 2009). So in total, a rate rise will generally mean that businesses are less profitable due to increased borrowing rates. They are also likely to be less profitable due to a decrease in discretionary spending by consumers. Investors will have other options that are more attractive than before the rate rise, which might make them rethink their share exposure. This all adds up to a decrease in the value of shares and the share market.

\subsection{Conceptual Framework}

Independent Variables

Dependent Variable

\begin{tabular}{|l|}
\hline Dividend per share \\
Sum of declared dividends \\
issued by a company \\
/ordinary share
\end{tabular}

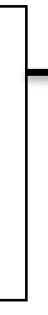

\section{Market Liquidity}

Average Annual Trade Volumes

\begin{tabular}{|l|}
\hline Market Capitalization \\
Total Value Of Shares \\
\hline Foreign Exchange rate \\
Annual foreign exchange \\
gains or losses
\end{tabular}

Perfomance Of Equity Prices After Initial Public Offer Of Firms Listed Nairobi Securities Exchange Average Annual Equity Share Prices

\section{Figure 1 Conceptual Framework}

\section{Source: Researcher (2021)}

\subsection{Research Methods}

The study used descriptive research design in the assessment of the macroeconomic effects of initial public offer and performance equity prices of firms listed in Nairobi Securities Exchange (NSE), Kenya. According to Nairobi Stock Exchange (NSE) Handbook on profiles and performance of listed companies, there were 7 firms that have issued IPO and this was the target population. The reason as to why listed companies were chosen was due to the availability and the reliability of the financial statement as they are subject to the mandatory audit by internationally recognized audit firm as well as regulators. The study used purposeful sampling design so as to encompass all the 7 registered firms in the Nairobi Securities Exchange that had issued IPO from 2011-2020. The major reason firms listed in Nairobi Securities Exchange were chosen is due to accessibility to the required data by the fact that it is a legal requirement for the companies Act Cap 482 for listed companies to publish their audited financial statements which will provide data required for this study. 
International Journal of Current Aspects in Finance, Banking and Accounting, Volume 3, Issue 2, 2021 PP 65-78, ISSN 2707-8035

The study used secondary data quantitative analysis that was acquired through analysis for the companies published annual account and quarterly market reports by the use of secondary data collection tool five years before and after IPO of the respective firms. Data was gathered using secondary data collection sheets. In order to establish the macroeconomic effects of IPO on performance of equity prices, panel data regression was used. Panel data usually gives the researcher a large number of data points, it therefore increases the freedom in one hand and decreases the collinearity on the other hand and thus the efficiency of econometric estimates was achieved or improved.

\subsection{Data Analysis Results}

For insights into the association between the dependent variable and independent variables focus was on the correlation analysis which was conducted to see the existence of multicollinearity. In addition, correlation analysis informs which variables should be dropped for having the same information (near perfect correlation). The correlations results is shown in Table 1.

Table 1 Pairwise Correlation Analysis Result

\begin{tabular}{|c|c|c|c|c|c|c|}
\hline & & $\begin{array}{l}\text { Equity } \\
\text { Price }\end{array}$ & $\begin{array}{l}\text { Dividend } \\
\text { per Share }\end{array}$ & $\begin{array}{l}\text { Market } \\
\text { Liquidit } \\
\text { y }\end{array}$ & $\begin{array}{l}\text { Market } \\
\text { Capitalization }\end{array}$ & $\begin{array}{l}\text { Foreign } \\
\text { Exchang } \\
\text { e Rate }\end{array}$ \\
\hline \multirow[t]{2}{*}{$\begin{array}{l}\text { Dividend } \\
\text { per Share }\end{array}$} & $\begin{array}{l}\text { Pearson } \\
\text { Correlati } \\
\text { on }\end{array}$ & $.129 * *$ & 1 & & & \\
\hline & $\begin{array}{l}\text { Sig. (2- } \\
\text { tailed) }\end{array}$ & .002 & & & & \\
\hline \multirow[t]{2}{*}{$\begin{array}{l}\text { Market } \\
\text { Liquidity }\end{array}$} & $\begin{array}{l}\text { Pearson } \\
\text { Correlati } \\
\text { on }\end{array}$ & $.448 * *$ & $.434 * *$ & 1 & & \\
\hline & $\begin{array}{l}\text { Sig. (2- } \\
\text { tailed) }\end{array}$ & .000 & .906 & & & \\
\hline \multirow[t]{2}{*}{$\begin{array}{l}\text { Market } \\
\text { Capitaliz } \\
\text { ation }\end{array}$} & $\begin{array}{l}\text { Pearson } \\
\text { Correlati } \\
\text { on }\end{array}$ & $.435^{* *}$ & .166 & .228 & 1 & \\
\hline & $\begin{array}{l}\text { Sig. (2- } \\
\text { tailed) }\end{array}$ & .001 & .646 & .527 & & \\
\hline \multirow[t]{3}{*}{$\begin{array}{l}\text { Foreign } \\
\text { Exchang } \\
\text { e Rate }\end{array}$} & $\begin{array}{l}\text { Pearson } \\
\text { Correlati } \\
\text { on }\end{array}$ & .89 & $.662 *$ & .368 & .354 & 1 \\
\hline & $\begin{array}{l}\text { Sig. (2- } \\
\text { tailed) }\end{array}$ & .806 & .037 & .295 & .316 & \\
\hline & $\mathrm{N}$ & 70 & 70 & 70 & 70 & 70 \\
\hline
\end{tabular}

**. Correlation is significant at the 0.01 level (2-tailed).

As shown by Table 1 all the independent variables; Dividend per share ( $\mathrm{r}=0.129 * *, \mathrm{P}=0.002)$, Market Liquidity $\left(\mathrm{r}=0.448^{* *}, \mathrm{P}=0.000\right)$, Market Capitalization $\left(\mathrm{r}=0.435^{* *}, \mathrm{P}=0.001\right)$ and Foreign Exchange Rate $(\mathrm{r}=0.89, \mathrm{P}=0.806)$ are positively associated with the share prices. The 
International Journal of Current Aspects in Finance, Banking and Accounting, Volume 3, Issue 2, 2021 PP 65-78, ISSN 2707-8035

effect was significant for all the variables except foreign exchange rate as the p-values were less than 0.05 implying that they are able to predict the changes in the equity share prices at any given time.

To establish the macroeconomic effects of IPO on equity share prices, panel data regression was used. Panel data usually gives the researcher a large number of data points and it therefore increases the freedom in one hand and decreases the collinearity on the other hand and thus the efficiency of econometric estimates was achieved. The results are shown in Table 2.

Table 2 Fixed effects of IPO on Equity Share Prices

\begin{tabular}{|c|c|c|c|c|c|}
\hline \multicolumn{4}{|c|}{$\begin{array}{l}\text { Random effects GLS regression } \\
\text { Group vari abl e: firm }\end{array}$} & $\begin{array}{l}\text { Number of obs } \\
\text { Number of groups }\end{array}$ & $\begin{array}{l}= \\
=\end{array}$ \\
\hline $\begin{array}{ll}- \text { sq: } & \text { wi t hi n } \\
& \text { bet ween } \\
& \text { overal I }\end{array}$ & $\begin{array}{l}=0.0154 \\
=0.9967 \\
=0.9885\end{array}$ & & & $\begin{aligned} \text { Obs per group: } & \text { mi } n \\
& \text { avg } \\
& \operatorname{mex}\end{aligned}$ & $\begin{array}{r}10 \\
10.0 \\
10\end{array}$ \\
\hline $\operatorname{cor} r\left(u_{-} i, x\right)$ & $=0$ (assume & & & $\begin{array}{l}\text { Wald chi } 2(4) \\
\text { Pr ob }>\text { chi } 2\end{array}$ & $\begin{array}{r}1318.32 \\
0.0000\end{array}$ \\
\hline Equit y & Coef. & Std. Err. & z & [95\% Conf. & . I nt er val ] \\
\hline $\begin{array}{r}\text { dps } \\
\text { Li qui di ty } \\
\text { Capi t al i zamn } \\
\text { for ex } \\
\text { _cons }\end{array}$ & $\begin{array}{r}16.86396 \\
2.77 \mathrm{e}-07 \\
2.25 \mathrm{e}-08 \\
-0064155 \\
4.769939\end{array}$ & $\begin{array}{r}4786921 \\
1.71 \mathrm{e}-06 \\
4.11 \mathrm{e}-07 \\
0211715 \\
6.511478\end{array}$ & $\begin{array}{r}35.23 \\
0.16 \\
0.05 \\
-0.30 \\
0.73\end{array}$ & $\begin{array}{r}15.92574 \\
-3.07 \mathrm{e}-06 \\
-7.82 \mathrm{e}-07 \\
-.0479108 \\
-7.992323\end{array}$ & $\begin{array}{r}\text { 17. } 80217 \\
\text { 3. } 63 \mathrm{e}-06 \\
8.27 \mathrm{e}-07 \\
.0350799 \\
17.5322\end{array}$ \\
\hline $\begin{aligned} \text { si grre_u } \\
\text { si grre_e } \\
\text { r ho }\end{aligned}$ & $\begin{array}{r}6.107685 \\
9.1110197 \\
.31005254\end{array}$ & ( f r act i on & varia & e due to $u_{-} i$ ) & \\
\hline
\end{tabular}

As shown by Table 2, F statistic is 0.00 and is less than the critical value at one per cent level of significance. Therefore, the variables are jointly significant in explaining the variations in equity share prices. The interclass correlation (rho) is 0.310 implying that $31 \%$ of the variations in equity share prices are due to differences among the quoted firms. The within and between R-square is 0.0154 and 0.9967 respectively. Thus, $1.54 \%$ of variations in the equity share prices are due to differences within individual firms and $2.01 \%$ of the variations are due to differences between the firms. The overall $\mathrm{R}^{2}$ is 0.9885 , indicating that the variables considered in the model account for about $98.85 \%$ percent change in the dependent variables, while the remaining percent change may be as a result of other variables not addressed by this model. Based on the coefficients, dividend per share improved the equity share prices while forex reduced equity.

Further, panel data regression was done with each dependent variable being regressed against dummy variable for IPO event. Period before the IPO was quoted 0 and after the IPO 1. As shown by Table 3, Dividend per share improved significantly after the IPO.

Table 3 Effect of IPO

\begin{tabular}{|l|r|r|r|r|r|}
\hline & $\begin{array}{l}\text { Dividend } \\
\text { per Share }\end{array}$ & $\begin{array}{l}\text { Market Liquidity } \\
\text { (Share Volume) }\end{array}$ & $\begin{array}{l}\text { Market Capitalization } \\
\text { (Total Value of Shares) }\end{array}$ & $\begin{array}{l}\text { Equit } \\
\text { yrice } \\
\text { Price }\end{array}$ & \multicolumn{1}{|l}{$\begin{array}{l}\text { Forex_g } \\
\text { ain_loss }\end{array}$} \\
\hline Coef & 0.4765714 & 83182.9 & 1702463 & 2.2917 & 14 \\
\hline $\begin{array}{l}\text { Std. } \\
\text { Err }\end{array}$ & 2.013649 & 424738.9 & & 34.701 & \\
\end{tabular}


International Journal of Current Aspects in Finance, Banking and Accounting, Volume 3, Issue 2, 2021 PP 65-78, ISSN 2707-8035

\begin{tabular}{|l|r|r|r|r|r|}
\hline & $\begin{array}{l}\text { Dividend } \\
\text { per Share }\end{array}$ & $\begin{array}{l}\text { Market Liquidity } \\
\text { (Share Volume) }\end{array}$ & $\begin{array}{l}\text { Market Capitalization } \\
\text { (Total Value of Shares) }\end{array}$ & $\begin{array}{l}\text { Equit } \\
\text { y } \\
\text { Price }\end{array}$ & $\begin{array}{l}\text { Forex_g } \\
\text { ain_loss }\end{array}$ \\
\hline $\begin{array}{l}\text { p- } \\
\text { value }\end{array}$ & 0.0000 & 0.6139 & & & \\
\hline $\begin{array}{l}\text { R- } \\
\text { squar } \\
\text { ed }\end{array}$ & 0.3859 & 0.1184 & 0.0000 & 0.0000 \\
\hline
\end{tabular}

\subsection{Conclusion and Recommendations}

\subsection{Conclusion}

The core objective of conducting this study was to establish the relationship between factors of equity prices after IPO (Initial Public Offer) of firms listed at the NSE. Fama and French (2004) document that over the last decades; more firms characterized by low profit/high growth went public which has decreased the average survival time of an IPO significantly. The study concludes that dividend per share, market capitalization and market liquidity improved in the post going public period. This is due to the proceeds received by companies from the sale of their shares to the public. This therefore implies that firms improve their liquidity position after going public.

The study also concludes that increase in investor recognition and shareholder base due to an IPO lowers the firm's cost of equity that enhances stock liquidity which is valuable for managerial incentive schemes, which in turn increases firm value which is reflected in rising share prices and returns. In addition, the study concludes that firms benefit by going public despite potentially higher agency problems, at least for the first few years after the IPO. Becoming publicly traded provides financial capital to firms that helps them commercialize their products. Therefore, companies that wish to go public should do so without misinforming the public on the position of their financial performance in order to sell their shares at a higher price than the shares' actual value.

\subsection{Recommendations to Policy and Practice}

The study recommends that underwriters, valuers and transaction advisors refine or completely re-examine their IPO valuation techniques and methods in order to prevent the gross overvaluation of IPOs. This because over valuing IPOs may adversely affect investors once these IPO enter the market. They can accomplish this primarily through better forecasting techniques that take into account the strengths, weaknesses, opportunities and threats faced by the companies as well as their particular industry and the economy in general. This study recommends the GoK to strengthen the Capital Market Authority. This will empower it to come up with mitigation measures to control the external determinant that disrupt the share prices with a possible measure to cushion NSE from international monetary fluctuations; moderation and control of interest rates particularly the strategic ones that can help in determination of stock price behaviour.

The study also recommends that CMA should encourage firms to list as doing so would increases investor recognition and shareholder base which would lower the firm's cost of equity and improves firm's value. Private firms should also be encouraged to list as doing so enhances stock liquidity which is valuable for managerial incentive schemes, and this in turn increases firm value. Establishment and strengthening of an independent public institution to monitor 
International Journal of Current Aspects in Finance, Banking and Accounting, Volume 3, Issue 2, 2021 PP 65-78, ISSN 2707-8035

and prevent dividend manipulation, stabilization of interest rates, EPS insurance against share losses for companies in Kenya the same way CBK does to the commercial banks in Kenya. This will necessitate establishment of an oversight committee.

\section{References}

Aamir, M., Nasir, A., Khan, K. and Qayyum, M. (2011). Can Dividend Decisions Affect the Stock

Prices: A Case of Dividend Paying Companies of KSE, Euro Journals Publishing, Inc., International Research Journal of Finance and Economics76(1).

Adesola, W., and Okwong, E. (2009). An Empirical Study of Dividend Policy of Quoted Companies in Nigeria. Global Journal of Social Sciences, 8 (1), 85-101.

Ahmad, N., and Hussin, W. (2010). Corporate governance and earnings forecast accuracy, Asian Review of Accounting, 18 (1).

Ahmad, N., Campbell, K., and Good, A. (2007). The long run share price performance of Malaysian Initial Public Offerings (IPOs), Journal of Business Finance \& Accounting 34, 78- 110 .

Ahmad, N., Campbell, K., and Good, A. (2011). Earnings management in Malaysian IPOs: The East Asian crisis, ownership control and post-IPO performance, International Journal of Accounting, 46 (2), 111-137.

Ahmed, H., and Javid, A. (2009). Dynamics and Determinants of Dividend Policy in Pakistan: Evidence from Karachi Stock Exchange Non-Financial Firms. International Journal of Finance and Economics 2, 148-171.

Akbar, M., and Baig, H. (2010). Reaction of Stock Prices to Dividend announcements and Market Efficiency in Pakistan. The Lahore Journal of Economics, 15 (1), 103 - 125.

Alile, H. I. (1992). Establishing a Stock Market - Nigerian Experience, Paper Presented at the Conference on Promoting and Developing Capital Markets in Africa, Abuja.

Amidu, M. (2007). How Does Dividend Policy Affect Performance of the Firm on Ghana stock Exchange? Investment Management and Financial Innovations, 4 (2), 103-112.

Bae. K, (2006). Business groups and tunneling: Evidence from private securities offerings by Korean Chaebols. Journal of Finance, 61, 2415-2449.

Baker, H. K., and Powell, G. E. (2012). Dividend Policy in Indonesia: Survey Evidence from Executives. Journal of Asia Business Studies, 6 (1), 79 - 92.

Baker, H. K., Mukherjee, T. K., and Paskelian, O. G. (2006). How Norwegian Managers View Dividend Policy. Global Finance Journal, 17 (1), 155-176.

Benartzi, B. and William C. ( 2007). The nominal price puzzle, UCLA working paper.

Central Bank of Kenya (CBK, 2008). Statistical Bulletin.

Daily, C.M. (2005). Investment Bankers and IPO Pricing: Does Prospectus Information Matter? Journal of Business Venturing, 20: 93-111

Demers, E. and Joos, P. (2007). IPO Failure Risk. Journal of Accounting Research, 45: 333371. Denis and Osobov (2008). Why Do Firms Pay Dividends? International Evidence on the Determinants of Dividend Policy, Journal of Financial Economics, 89, 62-82.

Dimitrova. D (2005). How Do Exchange Rates Affect the Stock Market? Leiden University press

Edmonston, P. (2009).Google's I.P.O. Five Years Later - NY Times. Dealbook.nytimes.com. Retrieved on 2012-10-16.

Hussainey, K., Chijoke, M., and Mgbame, M. (2011). Dividend Policy and Share Price Volatility: UK Evidence, Journal of Risk Finance, (12) : 57-68.

Ljungqvist, A. P. (2006). Hot Markets, Investor Sentiment, and IPO Pricing, Journal of Business, 79: 1667-1702 
International Journal of Current Aspects in Finance, Banking and Accounting, Volume 3, Issue 2, 2021 PP 65-78, ISSN 2707-8035

Nazir, M. S., Nawaz, M. M., Anwar, W., and Ahmed, F. (2010). Determinants of Stock Price Volatility in Karachi Stock Exchange: The Mediating Role of Corporate Dividend Policy.

Onagoruwa, O. (2006). Analysis Propose Antidotes to Down Trend in the Market. Stock Watch, 1(4):.3-8.

Paleari, S. and Vismara, S. (2007). Over optimism when Pricing IPOs, Journal of Managerial Finance, 33(6): 352-367

Siegel, N., and Ofer, J. (2007). Stocks for the Long Run (McGraw-Hill, New York).

Uddin, M. G., and Alam, M. (2007). The Impacts of Interest Rate on Stock Market: Empirical Evidence from Dhaka Stock Exchange. South Asian Journal of Management and Sciences, 1(2), 123-132.

Vaz, J.J., Ariff, M., and Brooks, R.D. (2008). Effect of Interest rate change on Bank stock returns, Investment Management and Financial Innovations, 5 (4), pp. 221-236.

This is an open-access peer reviewed article published and distributed under the terms

and conditions of the (c) (i) (8) Creative Commons Attribution 4.0 International License of United States unless otherwise stated. Access, citation and distribution of this article is allowed with full recognition of the authors and the source. Copyright, content ownership and liability for content herein remain with the authors. 